\title{
ŚWIĘTE KSIĘGI A CZASOPRZESTRZEŃ KULTUROWA
}

Wielkie księgi ludzkości, redakcja naukowa Anna Czajka, Wydawnictwo UKSW, Warszawa 2013, ss. 317.

Praca zbiorowa Wielkie księgi ludzkości wydana nakładem Uniwersytetu Kardynała Stefana Wyszyńskiego, pod redakcją naukową Anny Czajki, stanowi niezwykłe świadectwo wkładu środowisk akademickich w dialog kulturowy, szczególnie ważny u progu trzeciego millenium. Na wysoką ocenę zasługują sam dobór tematu, a także teoretyczne i praktyczne walory publikacji, nawet jeśli ma ona tylko zakreślić pole problemowe analiz planowanych jako cykl badawczy i wydawniczy. Koncepcja zbioru jest przemyślana, struktura przejrzysta, a kwestie warsztatowe i siatka kategorialna dowodzą spójności zamysłu. Zestaw autorów rozdziałów zbioru, wybitnych uczonych podejmujących w tym kontekście niecodzienne wyzwanie, już po pierwszym wglądzie zapowiada, że publikacja to inicjatywa atrakcyjna dla specjalistów i szerokich kręgów odbiorców.

Ważne jest także, skąd bije źródło, bo teksty konstruujące nowy wymiar dialogu cywilizacyjnego ukazały się pod egidą uczelni Kardynała Stefana Wyszyńskiego. Jako świadectwo zaangażowania środowisk uczonych XXI w. w trud rekonstrukcji wielkiego dziedzictwa przeszłości to niezwykłe dzieło jest po książce Kultury świata w dialogu (UKSW, 2012) drugą z kolei pozycją wydawniczą świadczącą o otwarciu uczelni o tradycjach chrześcijańskich na cywilizacje pozaeuropejskie, na gruncie filozofii, antropologii i kulturoznawstwa konstruującą perspektywę wyjątkową, zarówno jeśli chodzi o wagę podjętej tematyki, jak i w aspekcie interpretacyjnym. Jeśli dodać do tego fakt, że jest to przedsięwzięcie o charakte- 
rze encyklopedycznym, choćby ze względu na gęstość faktografii, oraz konfrontacyjnym, bo zorientowane na wielkie księgi kultury chińskiej, indyjskiej, arabskiej i żydowskiej, a także wziąć pod uwagę udział badaczy ze słynnych uniwersytetów Europy Zachodniej, należy potraktować sam zamysł jako próbę integracji interdyscyplinarnych, skoncentrowanych na wadze Ksiąg i przekazu Słowa nurtów badań prowadzonych w Polsce i poza nią - zazwyczaj w bardzo odległych od siebie formach i strukturach.

Wielkie uznanie budzi nie tylko sam projekt zestawienia kanonów tradycji dotyczących krańcowo różnych obszarów cywilizacyjnych i tradycji akademickich wyróżniających się pod tym względem uczelni europejskich, ale i konfrontacja warsztatów wybitnych badaczy i interpretatorów, których nigdzie dotąd w jednej przestrzeni badawczej czy nawet w przestrzeni jednego odbioru lingwistycznego nie udało się łącznie usytuować. To niezwykłe dzieło stanowi bowiem efekt nie tylko integracji środowiskowej zaistniałej w kontekście tej konkretnej tematyki pracy, ale jest owocem wędrówek i doświadczeń akademickich autorów bardzo oryginalnego zamysłu, w tym szczególnie autorki redakcji naukowej zbioru. Realizacja jest dobrym świadectwem trudu pogodzenia wybitnych osobowości i stylów pracy wybitnych osobowości będących przedmiotami i podmiotami badań, zasiadających przy jednym okrągłym stole w celu otwartego dialogu kultur i pokoleń, integrującego z wzajemnym dla siebie szacunkiem różne cywilizacje i epoki w dążeniu ku ponadczasowej Prawdzie. Tak skonstruowana perspektywa jedności problemowej jest atrakcyjna i czytelna zarazem.

O wadze tematyki i konstrukcji pracy świadczy nie tylko dobór specjalizacji autorskich, ale wybory wiodących wątków zorientowanych na wędrówkę wielkich tradycji. Wyeksponowanie cywilizacji chińskiej nie w kontekście izolacji i stagnacji, tylko poprzez przegląd starochińskiej klasyki, ale i w perspektywie uniwersalizacji konfucjanizmu, zarówno w czasie, jak i w przestrzeni Azji. W rozdziale Kanoniczne księgi chińskie Małgorzata Religa gruntownie porządkuje genetycznie, strukturalnie i hermeneutycznie zapisy starochińskiej mądrości, trzymając się klucza chronologicznego, związanego z ich ważnością w najstarszych epokach budowania jedności cesarstwa Państwa Środka. Komplementarnym, alternatywnym w odbiorze tekstem jest świetna interpretacja Krzysztofa Gawlikowskiego o uniwersalnej ekspansji konfucjanizmu, nie tylko inspirującego zręby państwowości takich regionów, jak: Japonia, Korea czy Indochiny, ale w samych Chinach wciąż odnawiającego swą żywotność, kryjącego się za kolejnymi renesansami tożsamości aż po najnowsze transformacje pozornie Konfucjusza zwalczające.

Należy tu dodać, że koncepcja Krzysztofa Gawlikowskiego jest na gruncie polskim wyprzedzającą znaki czasu pionierską interpretacją (vide: Nowa batalia o Konfucjusza, Warszawa 1976), przez co przysporzyła mu sporo kłopotów zarów- 
no w chylącym się do upadku PRL-u, jak i w obrębie ChRL w pamiętnych czasach „rewolucji kulturalnej”. Zacytowana tu oddaje mu sprawiedliwość, bo dziś nie tylko o dziedzictwo Mędrca spierają się Tajwan i Chiny kontynentalne, niedawno jeszcze diametralnie poróżnione w kwestii pozytywnej recepcji Konfucjusza. W odniesieniu zaś do strategii i prakseologii chińskiej ekspansji na Zachód w XXI w. może stanowić klucz do zrozumienia Chińczyków, w konfucjanizmie upatrujących możliwość uzdrowienia gospodarczej zapaści świata - jak też platformę jedności komunistów i diaspor Państwa Środka. Co do globalizacji konfucjanizmu, wystarczy sięgnąc do nowszych prac Krzysztofa Gawlikowskiego.

Tak daleko w sferze koherencji nie sięgają wywody o czasoprzestrzeni witalności cywilizacji indyjskiej. Należy tu przede wszystkim podkreślić precyzję i transparentny charakter narracji Marka Mejora w rozdziale Stowo Buddy - od tekstu mówionego do pisanego o uniwersalizacji buddyzmu rodem z Indii. Zakreślając drogę prowadzącą od charyzmatycznych kazań Gautamy Buddy do kolejnych kanonów indyjskich, ich tłumaczeń tybetańskich - wraz z komentarzami sięgających liczby kilkuset tomów, Marek Mejor przechodzi do interpretacji w kanonach starochińskich i japońskich oraz do ogromnego dorobku cejlońskiej i indochińskiej hinajany. Choć selekcja wątków niezbędna w tak krótkim z konieczności tekście budzi podziw dobrze pojętą skrótowością, przejrzystością i jasnością kryteriów wyboru, całości owej tematyki nie da się zawrzeć nawet w wyborze bogatej bibliografii. Wystarczy wskazać na skąpy wybór prac anglojęzycznych, pomijając opracowania niemieckie i francuskie, bo prawdziwe bogactwo zawiera informacja o zbiorze kilkudziesięciu tysięcy angloamerykańskich publikacji o buddyzmie podarowanych mi przez sygnującego tom Encyklopedia of Buddhist Bibliography Franka Reynoldsa na Uniwersytecie Chicago. Należy dodać, że odwołania Mejora do współczesności są z założenia skąpe i pośrednie.

Niedosyt budzi natomiast rozdział następny, tekst Moniki Nowakowskiej o genezie hinduizmu, po którym oczekujemy przedstawienia perspektywy kilku tysięcy lat tradycji indyjskiej, przez wieki rodzącej mędrców o wybitnych umysłach. Zabrakło tu intuicji Krzysztofa Gawlikowskiego, bo autorka ogranicza się do wedyzmu, a choć wspomina o Mahabharacie (i jej części - Bhagawadgicie) jako „Piątej Wedzie”, analizy filozofii powedyjskiej pomija nawet w bibliografii. Całość opracowania jest skrupulatna i precyzyjna, faktografia może być odkrywcza nawet dla specjalisty, a spójność interpretacji budzi podziw. Ale owo ograniczenie tworzy lukę, bo teksty choćby tylko mistyki i filozofii Wedanty pisali raz po raz indyjscy mędrcy niemal w każdym stuleciu epoki pochrystusowej, a w wieku XX przywódca niepodległych Indii - prezydent Sarvepalli Radhakrishnan i Mahatma Gandhi, który traktował Bhagawadgite jako tekst polityczny - wykładnię prakseologii gandyzmu. 
Choć pomysł rekonstrukcji dziedzictwa wielkich cywilizacji Dalekiego i Bliskiego Wschodu, na fundamentach określonych przez święte księgi-Koran, Wedy, Biblię, kanon buddyjski - nie jest w skali światowej zamierzeniem zupełnie nowym (wystarczy wspomnieć kompendium pod redakcją naukową Frédérica Lenoira i Ysé Tardan-Masquelier Le livre des sagesses. L'aventure spirituelle de l'humanité - zbiór tekstów obejmujący prawie 2000 stron, opublikowany w Paryżu w roku 2002), założenie redakcji naukowej omawianego tomu budzi podziw spójnością interpretacji zorientowanej na wędrówkę idei i wartości, spektakularnie zmieniającą ogromne regiony naszego globu. Interesujące są pod tym względem analizy adaptacji kanonicznych praźródeł tożsamości żydowskiej w dawnym Izraelu i poza nim, istotne w konfrontacjach mentalności diaspor z kulturami miejscowymi na kilku kontynentach. Tekst Anny Kuśnierek Święte Księgi Judaizmu. Starożytne przekłady Biblii $i$ ich status we wczesnym judaizmie wiąże się z kwestiami legitymizmu translacji kanonu (np. Septuaginta i aramejskie targuny). Status owych tłumaczeń zmieniał się przez wieki, grając w kulturze żydowskiej i jej adaptacjach lokalnych różne role. Powstanie państwa Izrael, sugeruje autorka, wiąże się z renesansem języka hebrajskiego i rewaloryzacją oryginałów kanonu biblijnego.

O inspiracjach chrześcijańskich kanonu starotestamentowego i spotkaniach z filozofią wyrastającą z cywilizacji starogreckiej traktuje świetny esej profesora Gerarda Cunica z Uniwersytetu Genui. Napisany dla zbioru Anny Czajki tekst Kant Reading the Bible znalazł miejsce w tomie tuż obok analizy Macieja Bały Paul Ricoeur reads the Bible, co stworzyło pole do porównania sposobów odniesień do fundamentów cywilizacji europejskiej z różnych punktów widzenia - wybitnego filozofa i słynnego religioznawcy. W tym wymiarze mieści się również podjęta w analizie Bernadetty Kuczery-Chachulskiej postawa Sołowiewa i Norwida wobec aksjologii Biblii - pierwszy wpłynął na duchowość Dostojewskiego, drugi na formację mistyczną Mickiewicza.

Odrębna, ale mieszcząca się w polu porównawczej refleksji nad podkreśloną we wstępie rolą Słowa i Księgi w kulturotwórczym procesie dojrzewania wielkich cywilizacji jest kwestia wielkiej wędrówki w przestrzeni etniczno-lingwistycznej. Ich status wyznaczała aura sacrum, broniąc przed deformacjami i marginalizacją możliwą w przypadku nieuprawnionych translacji, nad których rankingiem dyskutowano przez wieki. Uwagę zwraca tu tekst teologa Karla-Josefa Kuschela z uniwersytetu w Tybindze o roli Koranu w kulturze arabskiej w miarę eskalacji wpływów zderzanej z wielokulturowością i wielojęzycznością podporządkowywanych Arabom tradycji. Wprawdzie Koran jest księgą nigdy niestosowaną w aspekcie liturgicznym w wersjach tłumaczonych, co podkreśla Katarzyna Pachniak w eseju Koran, hadisy $i$ ich rola $w$ islamie, jednak jego prastare reinterpretacje spowodowały trwałe rozłamy, których konsekwencje objawiają się do dziś w dramatycz- 
nych konfrontacjach tożsamości wyznawców islamu szukających legitymizacji mentalności w historii Księgi i Słowa Mahometa.

Tom Wielkie księgi ludzkości jest wydarzeniem na naszym rynku wydawniczym. I to nie tylko dzięki rekonstrukcji relacji Księgi i Słowa jako centrum odniesień różnych prastarych i potężnych cywilizacji rodem z Azji, ale także w sferze wzajemnych, zróżnicowanych relacji owych pisanych i przekazywanych słowem fundamentów, stanowiących istotne tło wielkich konfrontacji historycznych, politycznych i uwarunkowań kulturowych. W wędrówkach wierzeń, idei i centralnych wartości owe cywilizacyjne orientacje zderzały się ze sobą - Słowo ze Słowem, Księga z Księgą - tworząc fundamenty współistnienia wielkich migracji ludów na nowych terenach ekspansji.

Zarysowana na początku konstrukcja pracy rozdziela wyjściową, bardzo szczegółową, precyzyjną i rzetelną informację o wielkich księgach cywilizacji chińskiej, arabskiej, judeochrześcijańskiej, indyjskiej i buddyjskiej od ich kolejnych, mniej lub bardziej swobodnych, kreatywnych recepcji, bardziej związanych z epoką współczesną. Ukazanie mapy kulturowych transformacji, wyznaczanej przez wpływy różnych kanonów liturgii, stopniowo wkraczających w ciążące ku nim grawitacyjnie struktury państwowości, cywilizacyjne konfiguracje i życie potoczne, stanowi o sukcesie tomu pod redakcją Anny Czajki, przecząc pozorom chaosu propagowanego w wielu nurtach ponowoczesnej, pospiesznie globalizowanej teraźniejszości.

Co więcej, sama tematyka jest ze swej istoty atrakcyjna zarówno dla wybitnych specjalistów, jak i dla szerokiego grona czytelników - poszukiwaczy sensu w globalnych transformacjach nowoczesności. Realizacja tego zamysłu świadczy o tendencji do interdyscyplinarnej integracji środowiskowej, wykraczającej poza główne nurty interpretacji wywodzące się w omawianym tomie głównie z kierunków trzech wybitnych uczelni warszawskich - kulturoznawstwa Uniwersytetu Kardynała Stefana Wyszyńskiego, studiów azjatyckich Szkoły Wyższej Psychologii Społecznej i orientalistyki Uniwersytetu Warszawskiego, ale i sięgające do ich powiązań z uniwersytetami w Genui i Tybindze.

Sytuowany w tym kontekście projekt jest porywający. Praca Wielkie księgi ludzkości stanowi swego rodzaju kompas w wędrówce przez pozorne morza braku ukierunkowania, bezsensu i nijakości epoki ponowoczesnej, przydatny badaczom i studentom religioznawstwa, orientalistyki, studiów azjatyckich i europeistyki, a także innym dyscyplinom humanistycznym, dla których jest ponad wszelką wątpliwość lekturą zalecaną i atrakcyjną w procesach pogłębionego wglądu w istotę dawnych i najnowszych przemian cywilizacyjnych. 